Acta Poloniae Historica

120, 2019

PL ISSN 0001-6829

\title{
Agnieszka Zabłocka-Kos
}

https://orcid.org/0000-0002-5602-6387

Institute of Art History, University of Wrocław

\section{THE 'MERCHANT SCHISM' IN BRESLAU: \\ A CHRISTIAN-JEWISH CONFLICT AND THE CONSTRUCTION OF THE EXCHANGE BUILDING IN THE FIRST HALF OF THE NINETEENTH CENTURY*}

\begin{abstract}
This article seeks to interpret the dispute between Christian and Jewish merchants that took place in Breslau (today, Wrocław in Poland) in the first half of the nineteenth century. ${ }^{1}$ The dispute arose in the eighteenth century and severely deepened after the reforms designed by Heinrich Friedrich Karl vom und zum Stein and Karl August von Hardenberg were being introduced in Prussia since 1807. Among other aspects, the conflict revolved around the rapid development of the local Jewish religious community and the fast expansion of its steam-gathering economic elite. The development of Silesian trade, with an enormous role of Jews in it, was accompanied by continuous attempts at regaining the Eastern markets, partly lost after Prussia annexed Silesia in 1740 as well as resulting from the decisions of the 1815 Vienna Congress. In order to restore Breslau as an intermediary in trade between the West and the East and make it an important stock-exchange hub, collective action was a must. However, conflicts between merchants of different religions, including keeping the Jewish merchants off the local exchange, obstructed the design. The dispute was partly averted when a Chamber of Commerce was set up in Breslau in 1849. However, only the gradual quitting by the Christian merchants, members of the merchant corporation, of their privileged position in the organisation of local trade gave way to a compromise. The construction in 1864-7 of a common 'exchange' can be perceived as epitomising the completion of a centuries-long dispute. The monumental

* This research was funded by the National Science Centre, Poland (Narodowe Centrum Nauki) as part of grant no. NN 105086835 entitled Rozwój architektoniczny $i$ urbanistyczny Wrocławia $w 2$. połowie XIX wieku na tle historii miasta.

${ }^{1}$ A comprehensive article on the dispute between Breslau's Christian and Jewish merchants is being prepared by Andreas Reinke.
\end{abstract}


edifice, the largest and the showiest of all exchange buildings east of Berlin at the time, testified to high aspirations of Breslavian economic circles and their keen willingness to develop trading business far beyond the then-frontier of the state. ${ }^{2}$

Keywords: Central Europe, Breslau (Wrocław), Cracow, eighteenth/nineteenth century, Christians, Jews, trade, commerce, merchants, Breslau Exchange, chambers of commerce

\section{I \\ SAVING THE BONDS BETWEEN BRESLAU TRADE AND EASTERN EUROPE}

"It, therefore, follows that the local commerce is in full blossom again and that Breslau, as a city of trade, also deserves its pride of place amongst the leading Prussian cities". ${ }^{3}$

Such was the hope for the development of trade in the Silesian capital city, as expressed in a monumental work of Breslavian statistics, published in 1866, along with the projected vision of making Breslau a central hub of commercial exchange between the West and the East again. The early 1860s certainly marked a prosperity period for the region of Silesia. This was connected with the remarkable economic recovery, rapid industrialisation and development of cities, and fast redevelopment and extension of railroad routes. The period's narratives on Silesian commerce and manufacturing frequently referred to Breslau's extensive trade contacts with the Polish-Lithuanian Commonwealth. In the time when Silesia was part of the Habsburg monarchy (1526-1740), Breslau's markets and fairs set the stage for intensifying exchange of commodity between the East and the West of Europe; overall, Breslau was one of the significant commercial and financial hubs in Central Europe. ${ }^{4}$ The former half of the eighteenth

${ }^{2}$ Agnieszka Zabłocka-Kos is working on her book, tentatively entitled Neither West nor East. The architecture of Breslau in the 1860s in the Central European context, presenting (among other things) a complete history of the Exchange building and offering its architectural and stylistic analysis in the context of the period's Central European art.

${ }^{3}$ Max von Ysselstein, Lokal-Statistik der Stadt Breslau (Breslau, 1866), 8.

${ }^{4}$ For an exhaustive discussion, see Józef Gierowski, 'Handel z Rzecząpospolitą i Wschodem' and 'Handel z innymi krajami', in Karol Maleczyński (ed.), Historia Ślaska, i (Until 1763), Part 3 (End 16 c.-1763) (Wrocław, 1963), 261-74; Herman Fechner, Wirtschaftsgeschichte der preußischen Provinz Schlesien in der Zeit ihrer provinziellen Selsbtständigkeit 1741-1806 (Breslau, 1907), 1-16, esp. 8-9, 96-8. 
century saw ever-increasing importance of the city's role as a transit place for goods from Western Europe and raw materials and products from the east of the continent. ${ }^{5}$ Native production developed intensively as well and was primarily exported to Poland and, further on, towards Asia. These relations were severely affected once Silesia was cut off from the Habsburg monarchy in $1740,{ }^{6}$ and Poland-Lithuania partitioned; all the same, Breslau's wealth was continuously based primarily upon its contacts with the East (as has repeatedly been remarked by historiographers).$^{7}$ The Napoleonic wars and, subsequently, the new division of Central Europe defined at the Congress of Vienna shook the foundation of the Breslau trade; the imposition of the new borders and customs tariffs after 1815 cut short the thitherto elaborated connections. ${ }^{8}$ Described once as the 'grand emporium' of wholesale trade (großes, mächtiges Handelsemporium) linking the west and the east, and the north and the south of Europe, the declining Breslau was systematically ousted from wholesale and transit trading operations. ${ }^{9}$ The importance of great fairs decayed, though the wool fair remained international well until the second half of the nineteenth century and was abolished only in the early twentieth. ${ }^{10}$ During the eighteenth and nineteenth centuries, Leipzig was taking over as the primary

${ }^{5}$ Gierowski, 'Handel z Rzecząpospolitą', 270-3.

${ }^{6}$ Silesia's trading relations in the Prussian time (until 1811) were analysed by Otto Scholz in the dissertation he submitted at the University of Breslau in 1915: Otto Scholz, Die Korporation der Kaufmannschaft zu Breslau (1339-1858), Part I (1339-1811). Beiträge zur Wirtschaftsgeschichte Breslaus (Breslau, 1915). At the present stage of research, the complete study has not been found; its 60-page-long fragment appeared in print as: Otto Scholz, Die wirtschaftspolitische Tätigkeit der Breslauer Kaufmannschaft unter königlich-preußischer Herrrschaft bis zum Jahre 1811 (Breslau, 1915). I am indebted to Mr. Andreas Reinke for making me aware of the Scholz study. Here, Scholz, Die wirtschaftspolitische, 5, 10-11.

7 The trade amounted, as of 1779, to approx. 3 million thalers in imported goods and not much less in exports; cf. Ysselstein, Lokal-Statistik, 11; Hermann Freymark, Die Handelskammer Breslau: 1849-1924. Festschrift der Industrie- und Handelskammer Breslau (Breslau, 1924), 76.

${ }^{8}$ Freymark, Die Handelskammer, 96 ff.; Hans Schneider, E. Heimann, 100 Jahre eines Breslauer Privatbankhauses (Breslau, 1919), 4-5.

${ }^{9}$ Freymark, Die Handelskammer, 78, 11-3; see Fechner, Wirtschaftsgeschichte, 725-6; Schneider, E. Heimann, 39.

${ }^{10}$ Richard Fischer, 'Geschichte des Breslauer Wollmarktes von seinen Anfängen bis zur Gegenwart', Beiträge zur Geschichte der Stadt Breslau, 4 (Breslau, 1938); Tomasz Afeltowicz, Studia nad historia banków śląskich (do roku 1918) (Wrocław, 1963), 53-4. 
exchange point between the East and the West and indeed grew to be the most active competitor to Breslau. ${ }^{11}$

Until the year 1846, Cracow functioned as the only "window to the East' and an "Eldorado for the Breslau merchantry". ${ }^{12}$ The hub was so important that merchants would establish their trading branch offices there, ${ }^{13}$ thus contributing to intensified contacts between economic elites of the two cities. ${ }^{14}$ The Vienna Congress resolutions made Cracow open for all the countries willing to do trading there. ${ }^{15}$ The city owed its status to the guarantee of duty-free transport of goods; there were years when up to a half of Silesian exports came through that market. ${ }^{16}$ And it was for this reason that Breslavians so much opted for having a railway connection with Cracow. ${ }^{17}$ The first plans to build a new line towards Upper Silesia were proposed in as early as the 1830s; they were more precisely formulated in 1840, in connection with the construction of the Austrian Kaiser Ferdinands-Nordbahn linking Vienna with Bochnia and Cracow. The hope was expressed at that point that the Silesian section of the railway will meet in Oświęcim with the planned railroad set from Warsaw, via Częstochowa, to the Austrian border, which would open enormous opportunities for Silesian exports. In parallel, it was expected that the announced line from Bochnia to Brody

${ }^{11}$ The Leipzig fair had doubtlessly owed much to the Polish-Saxon union and the Wettin rule in Poland in the first half of the eighteenth century. After the annexation of Silesia by Prussia, Frederick II tried to oppose the trend by organising a competitive fair in Breslau, which however did not survive long; cf. Fechner, Wirtschaftsgeschichte, 9-10.

${ }^{12}$ Schneider, E. Heimann, 56.

${ }^{13}$ Janina Bieniarzówna, Jan M. Małecki and Józef Mitkowski (eds.), Dzieje Krakowa, iii; Janina Bieniarzówna and Jan M. Małecki (eds.), Kraków w latach 1796-1918 (Kraków, 1979), 113; Schneider, E. Heimann, 77.

${ }^{14}$ No penetrating research has yet been done in respect of this particular topic. See Marian Haisig, Stefan Inglot, and Marian Wolański (eds.), 'Związki gospodarcze Śląska z resztą ziem polskich w okresie Tysiąclecia', Kwartalnik Opolski, xii (1966), 124-67; Zbigniew Kwaśny, 'Aussenhandel des Freistaates Kraków im Lichte von Berichte der preußischen Residenten', Studia Historiae Oeconomicae, ix (1974), 141-60.

${ }^{15}$ Bieniarzówna, Kraków w latach, 110-5.

${ }^{16}$ Stanisław Michalkiewicz (ed.), Historia Ślaska, ii: 1763-1850, Part 2: 1807-50 (Wrocław, 1970), 280-1.

${ }^{17}$ Agnieszka Zabłocka-Kos, Zrozumieć miasto. Centrum Wrocławia na drodze ku nowoczesnemu city 1807-1858 (Wroclaw, 2006), 256 ff. Cracow's first railway station was designed by Peter Rosenbaum, an architect from Breslau. 
and Lwów (Lemberg) would be constructed. The plans to connect Breslau with Western Europe by the railway to Dresden, with the North by the lines to Frankfurt-an-der-Oder and Berlin, and with the East allowed to make broad prospects for expansion. It was expected that making Breslau part of an international railway network will imply a reinstatement of the city's historical importance in European trade. ${ }^{18}$ It was envisioned that key connections between the Baltic Sea and the North Sea, on the one hand, and the Adriatic and Black Seas, on the other, would meet at the Silesian capital, thus paving the way to Asian markets. ${ }^{19}$ The other expectation was that Breslau would be well connected with Central European metropolises - Vienna, Berlin, Dresden, and Warsaw.

It was in Cracow that the idea was taken up, in 1840, to build a railway connection with Prussia: the expectations included commercial profits and transit opportunities for the transit of Western European commodity to India and China. ${ }^{20}$ To this end, a Society of Cracow-Upper Silesian Railway was set up. These concepts bore fruit, and a contract for construction of the Upper Silesian railroad's connection with Cracow was signed in March 1844 by members of the Upper Silesian Railway Society (Oberschlesische Eisenbahngesellschaft) and the Senate of the Free City of Cracow. ${ }^{21}$ The project's stakeholders were industrialist Friedrich Eduard von Loebbecke, ${ }^{22}$ Theodor

${ }^{18}$ For a detailed account on the concept of railroads designed to connect the West and the East, the North and the South of Europe and going through Breslau, see Michał Jerczyński and Stanisław Koziarski, 150 lat kolei na Ślasku (Opole and Wrocław, 1992), 15-22; Janusz Gołaszewski, 'Zarys dziejów węzła kolejowego we Wrocławiu na tle rozwoju sieci kolejowej na Śląsku', in Maria Zwierz (ed.), Wrocławskie dworce kolejowe (Wrocław, 2006), 61-100, here esp. 62-79; Hermann Freymark, 'Die Entstehung des Schlesischen Eisenbahnnetztes', in Erich Obst and Hermann Freymark, Die Grundlagen der Verkehrsentwicklung Schlesiens und die Entstehung des schlesischen Eisenbahnnetzes (Breslau, 1942), 35-168.

${ }^{19}$ Freymark, 'Die Enstehung', 49.

${ }^{20}$ Adrian Rams, 170 lat Kolei Krakowsko-Górnoślaskiej w Szczakowej: przeszłość, teraźniejszość, perspektywy (Jaworzno, 2017), 15-20, here 18; Juliusz Demel, Początki kolei żelaznej w Krakowie (Kraków, 1954), 15.

${ }^{21}$ Freymark, 'Die Enstehung', 83, has erroneously 1845; see Rams, 170 lat, 17.

22 Jan Harasimowicz (ed.), Encyklopedia Wroctawia (Wrocław, 2000), 460. Loebbecke was a secret commercial counsel, banker, trader in colonial merchandise and wool, owner of a forwarding business and appointed-administrator trade; see Verzeichniss sämtlicher bei der Börse recipierten Mitglieder der wohllöblichen Kaufmannschaft in Breslau (Breslau, 1843), 13. 
Reimann, ${ }^{23}$ and Johann Christian Schiller - on the part of Breslau; ${ }^{24}$ and, for Cracow, noted entrepreneurs, bankers and merchants Jan Bochenek, Wincenty(?) Kirchmajer, Wincenty(?) Wolf, and Antoni(?) Helcel (Höltzel). ${ }^{25}$

This superb concept was squandered by the liquidation of the Republic of Cracow after the 1846 Cracow Insurrection: the area was incorporated in January 1847 in the Kingdom of Galicia and Lodomeria and became part of the Austrian customs zone. The opening of a railway station in Cracow in the same year crowned a farsighted idea which was, however, turned down. The trading bonds between Prussia and Saxony, on the one hand, and the East, on the other, via Cracow were eventually severed, which led to an active protest among Breslau's merchants. In as early as November 1846, they sent a delegation to Berlin, composed of Julius Pinder, Chief Burgomaster (Oberbürgermeister) of Breslau, and exponents of the local merchants: the Catholics Johann Friedrich Jakob Theodor Molinari (known as Theodor Molinari), heading the Christian merchant corporation (kaufmännische Korporation); Karl August Milde, a significant Silesian entrepreneur; ${ }^{26}$ and Louis Dyhrenfurth, who represented the Jewish milieu. ${ }^{27}$ They had talks at three ministries - for Finance, Foreign Affairs and Internal Affairs - and obtained the audience with King Frederick William IV. After their talks ended up in a fiasco, Pinder travelled to Vienna to

${ }^{23}$ Owner of a forwarding company and a trade agency business, Reimann traded in dyes; cf. Verzeichniss sämtlicher, 16.

${ }^{24}$ Schiller was a royal commercial counsel, forwarding company and a trade agency business (registered as 'F. Schiller'); cf. Verzeichniss sämtlicher, 17.

${ }^{25}$ Bieniarzówna, Kraków w latach, 114, 117; Jan Ptaśnik, Z dziejów krakowskiego kupiectwa od XIV do XIX wieku (Kraków, 1910), 60-1; Józef Tadeusz Louis, Kupcy krakowscy w epoce przejściowej (1773-1846) (Kraków, 1883).

${ }^{26}$ Hans Jaeger, 'Milde, Karl August', Neue Deutsche Biographie, 17 (1994), 504-5 (online version): https://www.deutsche-biographie.de/pnd117041483. html\#ndbcontent [Accessed: 5 Dec. 2019]; Karl Wippermann, 'Milde, Karl August', in Allgemeine Deutsche Biographie, herausgegeben von der Historischen Kommission bei der Bayerischen Akademie der Wissenschaften [ed. by the Historical Commission, Bavarian Academy of Sciences], xxi (1885), 733-7; for a complete digital edition, see Wikisource: https://de.wikisource.org/w/index.php?title=ADB:Milde, _Karl_ August\&oldid $=$ [Accessed: 10 July 2019].

${ }^{27}$ Dyhrenfurth, alias Dyrenfurth, was a commercial counsel and proprietor of a large suburban area (Pöpelwitz/Popowice); see Johann G. Knie, Alphabetischstatistisch-topographische Uebersicht der Dörfer, Flecken, Städten und andern Orte (Breslau, 1845), 499. 
seek support at the local ministries - to no avail again, though. ${ }^{28}$ In 1848, the merchants of Breslau petitioned the National Assembly (Nationalversammlung) in Frankfurt-am-Main for incorporating Austria, together with Galicia and Cracow, in the German Customs Union (Deutscher Zollverein). Another such petition, in a revised version, was put forward by Breslau's Chamber of Commerce in 1866, in the course of the Austro-Prussian War, and demanded annexation of Cracow to Silesia. ${ }^{29}$ These actions, with no successful outcome, confirm that merchants of Breslau made tireless attempts at sustaining beneficial commercial contacts with Cracow and, through and via it, with Eastern Europe.

Demarcation of the new state borders, establishing customs barriers, and the fast-increasing role of railway connections led to a reorganisation of international trade centres within Central Europe. Attempts to rebuild Breslau's former business connections with the east of Europe were translated in the 1830s and 1840s into the planning and construction of railroad routes. However, the rival Saxon-Austrian projects for new railroad networks, which strove to eliminate Prussian railways from lucrative commercial routes, posed a threat to Breslau as well. ${ }^{30}$ The redevelopment of the seaport in Trieste brought about an important change; ${ }^{31}$ the opening, in the early fifties, of a direct railway connection between Prague and Dresden decisively contributed to the development of a major European trunk-line, with the resulting marginalisation of Breslau. In consequence, the Breslau commerce underwent a reorientation, and the new railway lines now extended from Breslau northwards to Posen (Poznań) and Stettin (Szczecin), within the German Customs Union. As a result, the Central Railway Station (called 'Main' today) opened in 1856;32 as Breslau's Chamber of Commerce remarked in its 1851 annual report: "Our wishes are primarily focusing on sustenance and development of the Customs

28 These endeavours are minutely discussed in Julius Stein, Geschichte der Stadt Breslau im neunzehnten Jahrhundert (Breslau, 1884), 230-4, here 233.

${ }^{29}$ Freymark, Die Handelskammer, 99.

${ }^{30}$ Hans-Friedrich Gisevius, Zur Vorgeschichte des preußisch-sächsischen Eisenbahnkrieges. Verkehrspolitische Differenzen zwischen Preußen und Sachsen im Deutschen Bund (Berlin, 1971).

${ }^{31}$ Freymark, Die Handelskammer, 12, 99.

32 Zabłocka-Kos, Zrozumieć miasto, 350 ff.; Jolanta Gromadzka, 'Dworzec Główny', in Zwierz, Wroctawskie dworce, 165-86. 
Union that would extend as far the Northern Sea, on incorporation of all the north-German lands therein; entering into a commercial union with Austria, with possibly far-reaching reciprocal compromise, would come second". ${ }^{33}$

Nonetheless, the willingness to reinstate the eastern direction for commerce was continually urgent - and this was attested not only by Breslavian merchants' intensive campaign for abolishment of customs barriers between Prussia and Russia but also, and primarily, by pushing forward the construction of a direct railway connection between the Silesian capital and Warsaw. ${ }^{34}$ The opening in 1861 of the railway line from Riga, via Dünaburg (now Daugavpils, Latvia), to Petersburg and Warsaw triggered an instant response from Breslau's merchants who claimed that the work on a direct connection with the capital of the Kingdom of Poland should be accelerated. The need for the Prussian government to become more engaged in the talks with Russia was strongly emphasised, and high hopes were attached to this diplomatic offensive. As representatives of Breslau's Chamber of Commerce stressed in 1862: "Russia must herself conclude that joining the European customs system would contribute to uplift her culture and that the only means to accelerate this conclusion is the possibly immense support for trading in commodities smuggled into Russia". ${ }^{35}$ Around the middle of the nineteenth century, Breslau's economic circles diversified the directions of export and import of goods: along with the enormously important internal - that is, Silesian - market, new markets were sought within the Customs Union, along the lines of political realities.

II

THE ROLE AND POSITION OF JEWS IN BRESLAVIAN TRADE

Nonetheless, eastern markets were never neglected in the third quarter of the nineteenth century - on the contrary, tapping them was perceived as an opportunity for the Silesian industry and trade. The former intercity connections based on the Via Regia route had been replaced

${ }^{33}$ Freymark, Die Handelskammer, 100. The annual Jahresbericht der Handelskammer $z u$ Breslau dealt a great deal with new railway lines and their importance to Silesian trade - in the 1850s and 1860s, on an annual basis.

34 Freymark, Die Handelskammer, 116-7.

35 Ibidem, 108. 
by new railway lines; now that they had been functioning for ten years, their significance for Central European trade became evident. Jewish merchants and bankers, from Breslau as well as the former Polish-Lithuanian territory, importantly contributed to keeping up these connections and associations. These relationships dated back to the seventeenth century. However, the history of Jewish trade and commerce was marked by conflicts between Christian merchants and those of Mosaic religion, persisting since the early modern era and intensifying in the former half of the nineteenth century - the period when expansion toward the East became so crucial for the Breslau economic circles. This brought about a deadlock as attempts were made to re-establish the relations with Eastern markets, on the one hand, while Christian merchant circles shied away from considering their Jewish counterparts to be equal business partners. Restoring these contacts was much difficult without Jewish intermediation. Meanwhile, the dispute between the two circles in Breslau peaked in the 1840s and 1850s.

The origins of the conflict dated to the seventeenth century. Since the Habsburg time Jews played an important role as agents in trade between Polish and German merchants. ${ }^{36}$ The seventeenth century saw a gradual rebirth of the Breslau religious community, previously smashed by the fifteenth-century pogroms ${ }^{37}$ The privileges and charters

${ }^{36}$ Israel Rabin and Bernhard Brilling have examined this problem in detail, basing on abundant source material (only partly extant today); see Israel Rabin, Vom Rechtskampf der Juden in Schlesien 1582-1713 (Breslau, 1927); Israel Rabin, Beiträge zur Rechts- und Wirtschaftsgeschichte der Juden in Schlesien im 18. Jahrhundert, i: Der rechtliche Zustand (1713-1740) (Breslau, 1932); Bernhard Brilling, Geschichte der Juden in Breslau von 1454 bis 1702 (Stuttgart, 1960); id., 'Geschichte der Juden in Breslau (1702-1725)', in Jahrbuch der Schlesischen Friedrich Wilhelms Universität zu Breslau, xvi (1971), 88-126. Commercial connections with Polish territory prior to the Partitions of Poland-Lithuania and afterwards are exquisitely illustrated by the surviving files of the merchants' exchange: State Archives in Wroclaw (hereinafter: APWr), fond: 'Archiwum Giełdy Kupieckiej', ref. no. 82-304-0. The content of these files has not been thoroughly examined yet.

${ }^{37}$ Manfred Agethen, 'Die Situation der jüdischen Minderheit in Schlesien unter österreichischer und unter preußischer Herrschaft', in Peter Baumgart (ed.), unter Mitwirkung von [in collaboration with] Ulrich Schmilewski, Kontinuität und Wandel. Schlesien zwischen Österreich und Preußen (Sigmaringen, 1990), 307-31; Arno Herzig, 'Die Juden Breslaus im 18. Jahrhundert', in Manfred Hettling, Andreas Reinke and Norbert Conrads (eds.), In Breslau zu Hause? Juden in einer mitteleuropäischen Metropole 
they received from the emperors concerned the right to settle in Silesian towns, trading on local and international levels, and running the royal mint. By means of a privilege passed by Ferdinand II in 1627-8, the Jews were offered freedom of travel, participation in fairs and trade training, in exchange for high taxation; in turn, the Jews received the same privileges as the Christian merchants with respect to customs duties, fees and charges. ${ }^{38}$ Merchants from Poland, Russia and Ukraine were the most important commercial agents who enabled exports of commodities far into the East - to Russia, Moldavia, and Walachia. ${ }^{39}$ They could unrestrainedly travel across Silesia and were exempt from export duty fees. ${ }^{40}$ In the latter half of the seventeenth century Breslau's city council consented to the opening of Jewish representative offices called Schammeses, ${ }^{41}$ which represented the Jews' commercial and legal interests during their absence in Breslau - in the periods between fairs - and organised religious ministry in the form of services and prayer houses. As of 1696, Schammeses are reported to have represented Jews from Bohemia (Prague, Moravia), Silesia (Glogau/Głogów, Zülz/Biała Prudnicka), and Poland. The Schammes from Krotoschin (Krotoszyn) represented Greater Poland (Wielkopolska), the one from Cracow represented Lesser Poland (Małopolska), from Lwów - Podolia and Galicia. The Jews from Poznań, Leszno and Rzeszów also had a Schammes. ${ }^{42}$ Territorial synagogues developed around their seats, testifying to extensive commercial contacts with the area of Poland-Lithuania (the synagogues of Kalisz, Leszno, Krotoszyn, Lwów and Volhynia and Lithuania). ${ }^{43}$ The emperor as well as Silesian noblemen and merchants supported the presence of Jews from Poland, perceiving them as indispensable intermediaries in the commercial exchange with the East of Europe. ${ }^{44}$ This was

der Neuzeit (Hamburg, 2003), 46-62, containing quite an extensive discussion of business contacts between Polish and Silesian Jews.

${ }^{38}$ Rabin, Vom Rechtskampf, 39-40.

${ }^{39}$ Brilling, Geschichte der Juden in Breslau von 1454 bis 1702, 14-6, 43-5.

40 Ibidem, 16; Agethen, 'Die Situation der jüdischen', 311.

${ }^{41}$ Brilling, Geschichte der Juden in Breslau von 1454 bis 1702, 28, 37-42.

42 Ibidem, 41; Leszek Ziątkowski, Dzieje Żydów we Wrocławiu (Wrocław, 2000), 20.

${ }^{43}$ Leszek Ziątkowski, 'Synagogi we Wrocławiu od XVII do XX wieku', in Jerzy Rozpędowski (ed.), Architektura Wroctawia, iii: Światynia (Wrocław, 1997), 351-74.

${ }^{44}$ Leszek Ziątkowski, Między niemożliwym a koniecznym. Reformy państwa pruskiego w końcu XVIII i na początku XIX wieku a proces równouprawnienia Żydów ze szczególnym uwzględnieniem sytuacji na Ślasku (Wrocław, 2007), 113-5. 
attested by the Edict of Toleration (Toleranzedikt) issued by Emperor Charles VI in $1713,{ }^{45}$ which regulated the issues of taxes incumbent upon native as well as foreign Jews. The Jews were categorised into six tax groups, and their settlement rights were remarkably extended. The patent was meant to foster Jewish settlement, including Jews from Poland, and enliven the economy that collapsed after the Northern Wars and to strengthen commercial competition from Saxony (Polish-Saxon union) and Brandenburg. ${ }^{46} 1727$ saw Charles VI announce a rescript ensuring 'complete toleration' (vollständige Toleranzfreiheit) to Polish Jews, ${ }^{47}$ which translated into economic aspects as well.

The privileges granted to Polish Jews were sustained, and even extended, under the Prussian rule; the Jews would enjoy special benefits and facilitations in commerce, since eastern trade continued to be the economic priority for Silesia. ${ }^{48}$ Resulting from the restrictions imposed by Frederick II in 1744, right after Silesia was annexed by Prussia, on the non-acceptance-of-Jews privilege (Privilegium de non tolerandis Judaeis) that had functioned since $1455,{ }^{49}$ Jewish people arriving mainly from the areas of Poland-Lithuania and Bohemia began settling in the city. ${ }^{50}$ As has been demonstrated by Ziątkowski, in 1742, 29 per cent of Breslau's Jews declared that they had arrived from Poland, incl. 22.7 per cent from Greater Poland, whilst 11 per cent came from Bohemia and Moravia. The privileges related to temporary stay in Silesia were extended for their use; merchants from Poland could enter

${ }^{45}$ Rabin, Beiträge zur Rechts- und Wirtschaftsgeschichte, 84, 313; Helga Schuster, Die jüdische Bevölkerung Schlesiens im 18. Jahrhundert. Ein Vergleich der Gesetzgebung Karls VI. und Friedrichs II. Magisterarbeit, Universität Wien (Wien, 2010), 60-7.

${ }^{46}$ Rabin, Beiträge zur Rechts- und Wirtschaftsgeschichte, 43.

47 Ibidem, 58, ftn. 161.

${ }^{48}$ Agethen, 'Die Situation der jüdischen', 319-20.

${ }^{49}$ Although, as Ziątkowski emphasises, the privilege remained in force (in legal terms) until 1812; see Ziątkowski, Między niemożliwym, 123.

50 Ziątkowski, Między niemożliwym, 100-34; Ingo Loose, 'Die Juden in der Wirtschaft Schlesiens von der Reichsgründung 1871 bis zur Schoah. Die Wirtschaft Schlesiens von 1871 bis zum Ersten Weltkrieg;, in Andreas Brämer, Arno Herzig und Krzysztof Ruchniewicz (eds.), Jüdisches Leben zwischen Ost und West. Neue Beiträge zur jüdischen Geschichte in Schlesien, series: Hamburger Beiträge zur Geschichte der deutschen Juden, 44 (Göttingen, 2014), 156-216, here 157; Konrad Fuchs, 'Jüdisches Unternehmertum in Schlesien' in Menora. Jahrbuch für deutsch-jüdische Geschichte, v (1994), 71-94, here $71 \mathrm{ff}$. 
Breslau unrestrainedly and stay there for as long as they wished, ${ }^{51}$ which formed the basis for development of tight commercial contacts with areas east of Prussia.

The subsequent regulations, from the years 1757 and 1790, enabled the full-fledged functioning of the Jewish community and its fast demographic development, crowned by the 'Emancipation Edict' (Edikt betreffend die bürgerlichen Verhältnisse der Juden in dem Preußischen Staate) of 11 March $1812 .{ }^{52}$ The Edict caused that Prussia became a very attractive area for Jews, mainly from Galicia, to settle down. Silesia, especially Breslau, was the first stop on their way to the West. The doubling of the Jewish population in Silesia between 1803 and 1843 was also due to the internal emigration, especially from Greater Poland, where - under the Judenordnung adopted locally in 1833 - the freedom of practicing the profession by Jews continued to be strictly rationed. ${ }^{53}$

In 1867 , Jews accounted for 7.31 per cent of Breslau's population $(12,574 \text {, against the total of } 172,000 \text { number-wise })^{54}$ - the highest per-cent share of Jews in the Silesian capital ever. Breslau's Jewish community was the second largest in Prussia, after the one of Berlin, and the third largest in Germany, preceded by those of Berlin and Frankfurt am Main. It was primarily composed of Jews coming from Silesia, but (as remarked earlier) a considerable number came from Greater Poland, with rather few Jews from the Kingdom of Poland or Russia. ${ }^{55}$ The local Jewish minority was thus composed of people of diverse descents and wealth statuses. Let us stress that after 1853 as many as 31 per cent voters in Breslau, of the first - the most affluent - electoral class, were of Jewish descent. ${ }^{56}$ According

51 Ziątkowski, Między niemożliwym, 126-7.

52 Ibidem, $139 \mathrm{ff}$.

53 Annegret H. Bramer, Judenpolitik und Judengesetzgebung in Preußen 1812 bis 1847. Mit einem Ausblick auf das Gleichberechtigungsgesetz des Norddeutschen Bundes von 1869 (Berlin, 1987), 368-72.

${ }^{54}$ Ziątkowski, Dzieje Żydów, 49; Leszek Ziątkowski, Ludność żydowska we Wrocławiu w latach 1812-1914 (Wrocław, 1998), Table 9.

55 Ziątkowski, Ludność żydowska, Table 23 - referring to the year 1880; Ziątkowski, Dzieje $\dot{Z} y d o ́ w, 50-1$. It however seems that the inflows of Jews from the former Polish-Lithuanian territory, particularly to Breslau, still calls for detailed research.

56 Teresa Kulak, Historia Wrocławia, ii: Od twierdzy fryderycjańskiej do twierdzy hitlerowskiej (Wrocław, 2001), 195. 
to the Preußische Statistik for 1861-2, Breslau's Jews mainly dealt with trading (wholesale, to a large extent) - with 2,311 persons involved (according to the statistics, there were 2,518 Christians dealing with commercial activities), which accounted for 64.6 per cent Jewish and 47.8 per cent all merchants. ${ }^{57}$ This statistics shows how dynamic and well-off and thus influential group was formed by Jewish economic circles in Breslau around the middle of the nineteenth century. The lists of the community's members drawn up for the purpose of determining the synagogal tax give an idea of these people's affluence. ${ }^{58}$

Given the fast changes in the functioning of the merchant class (as a broad concept), implied by the reforms designed by Stein and Hardenberg and put into practice, a rapid development was seen in manufacturing, trade, and banking. After 1815 the Silesian capital saw a frenetic growth, to which the demolition of the fortifications (from 1807 on) and unrestrained development of suburban areas contributed. ${ }^{59}$ As of 1817, the population exceeded 70,000 and grew to almost 172,000 within fifty years. East of the Oder River, Breslau grew to be the largest city in this part of Europe, second only to Warsaw. ${ }^{60}$ Between 1825 and 1855, the number of merchants in

${ }^{57}$ Till van Rahden, Juden und andere Breslauer. Die Beziehungen zwischen Juden, Protestanten und Katholiken in einer deutschen Großstadt von 1860 bis 1925 (Göttingen, 2000), 44-5, 51-94. Also, cf. Ziątkowski, Ludność żydowska, Table 40, showing the professional mix of Jewish newlywed sons and their fathers. In 1837-42 and 1860-4, over 82 and 90 per cent fathers and sons dealt with trading in goods - a job that was plainly predominant among the Jewish population.

${ }^{58}$ Jewish Historical Institute (Żydowski Instytut Historyczny - hereinafter: ŻIH), 'Akta Wrocławskiej Gminy Żydowskiej', ref. no. 105/354: list of all payers of the synagogal tax, as of 1857 , specifying 2,172 persons in the city and fifteen in the district of Breslau. The list specifies the profession, income (estimated by individual community members on their own, in correlation with the municipal administration statistics) and the amount of tax paid, 3-120. On pp. 119-20 lists the most affluent members of the community. The files contain extant lists of community members paying the community tax. Apart from the first names and surnames, professions, abodes, and estimated incomes are specified. The earliest such list dates to 1857 (ŻIH 105/354), then come those from 1867 (ŻIH 105/355), 1873, up to 1912 (ref. nos. ŻIH 105/340 to 105/357). Never penetratingly analysed so far, the lists form an excellent source useful in studying the community's affluence, professional mix, and sociotopography.

${ }^{59}$ Zabłocka-Kos, Zrozumieć miasto, 19-52.

${ }^{60}$ Warsaw's population in 1864 was 223,000, Riga's equalled 102,000 in 1867. 
Breslau increased from 457 to 1,$080 ; 61$ of those dealing with trade/ commerce $-2,018$ to $2,841,{ }^{62}$ and of craftsmen/artisans - 893 into $1,238:^{63}$ altogether, a professional group of more than five thousand people. The affluent part of this group was an opinion-making elite, formed of taxpayers of significant importance to the state's and city's budgets. Their exponents co-managed the city of Breslau, ${ }^{64}$ the province and the state - as city councillors, members of the Provincial Parliament and the Prussian Parliament. They formed the decisive group of voters and elected members of parliamentary and local-government bodies; this was guaranteed to them by the new electoral law of 1853 , whereby the most affluent were preferred above all the others. ${ }^{65}$ Jews, mostly representing the merchant class, formed a part of the opinion-making elite. ${ }^{66}$

However, only a fifth of all the merchants and artisans formed the merchant corporation in Breslau until the emergence of the local Chamber of Commerce in $1848 .{ }^{67}$ The Chamber operationally reported to the Prussian Landrecht ('national law'; officially called 'the Universal National Law for the Royal Prussian States' [Allgemeines Landrecht für die Preußischen Staaten]) of 1794. The Law defined the notion of 'merchant' in quite simple terms - as one who trades in goods or exchange as his primary activity ${ }^{68}$ It was emphasised that the merchant's right is vested in the one who belongs to the merchant corporation. ${ }^{69}$ As per

${ }^{61}$ Ysselstein, Lokal-Statistik, 51, classes them as 'Klasse A: Kaufleute mit kaufmännischen Rechten', meaning merchants holding rights, which is registered merchants, usually dealing with wholesale trading, mostly Christians.

${ }^{62}$ Ysselstein, Lokal-Statistik, 51: 'Klasse B: Handelstreibende', i.e. those dealing with trading, mainly retail. Unregistered merchants (incl. Jewish merchants/doorto-door salesmen) were probably included.

${ }^{63}$ Ysselstein, Lokal-Statistik, 51: 'Klasse H: Handwerker'.

${ }^{64}$ As provided for by the new 'Regulations on Cities and Towns' passed in 1808.

${ }^{65}$ Kulak, Historia Wroctawia, $194 \mathrm{ff}$.

${ }^{66}$ The elites of Breslau, including their Jewish members, have not been penetratingly researched by historiographers as yet.

${ }^{67}$ Freymark, Die Handelskammer, 14.

68 'Wer den Handel mit Waaren oder Wechseln als sein Hauptgeschäft treibt, wird ein Kaufmann genannt', in Allgemeines Landrechtfür die Preußischen Staaten (Berlin, 1794), Zweiter Teil, Achter Titel, VII Abschintt [Part 2, Title 8, Section VII], $\$ 475$ (https://opinioiuris.de/quelle/1623\#Siebenter_Abschnitt._Von_Kaufleuten [Accessed: 10 Aug. 2019].

${ }^{69}$ Allgemeines Landrecht, $\$ 480$ : "An Orten, wo dergleichen Innungen bestehen, hat nur der, welcher darin aufgenommen ist, die Rechte eines Kaufmanns" (https:// 
Paragraph 585 of the Law, Jews could hold the rights of Christian merchants provided that they were the corporation's members.

In spite of the reforms put into practice in 1810 and 1811, the law from 1794 was still in force with respect to performing the profession of merchant and membership with the corporation. The law was additionally extended by means of the Law on economic activity from $1811 .{ }^{70}$ Although benefiting from various privileges and edicts granted on them in the Habsburg and Prussian time, Breslau's Jews were not admitted in the merchant corporation. ${ }^{71}$ Breslavian merchants were categorised into registered and unregistered (recipierte and nicht-recipierte Kaufleute) ${ }^{72}$ The recipierte Kaufleute were merchants who held full rights guaranteed by the Prussian Landrecht and the later relevant laws; this gave them the right also to participate and trade at the stock exchange. Being non-Christians, Jews were classed as belonging to the nicht-recipierte Kaufleute, and thus could not join stock exchange transactions. This split appeared glaringly contradictory to the prevalent trend in forming merchant organisations in Prussia after 1815.

opinioiuris.de/quelle/1623\#Siebenter_Abschnitt._Von_Kaufleuten [Accessed: 10.07.2019].

70 "Das Gesetz über die polizeilichen Verhältnisse der Gewerbe vom 7. September 1811". This law was in force until the new law on economic activity (Allgemeine Gewerbeordnung) was passed in 1845; see Freymark, Die Handelskammer, 7-8.

${ }^{71}$ The admission was conditioned not only by the declared religious confession but also by the completed traineeship with a Christian merchant, which eliminated Jewish candidates in a twofold manner, yet another condition having been holding of the city's citizenship; see Ysselstein, Lokal-Statisik, 125.

${ }^{72}$ Recipiert/nichtrecipiert can roughly be described as 'registered'/'unregistered' (Michalkiewicz describes these groups, respectively, as merchants holding and not holding the rights [Polish: kupcy $z$ uprawnieniami/ kupcy bez uprawnień]; see Michalkiewicz, Historia Ślaska, 269. Wholesale merchants were of primary importance among them. The first list was published in 1818: Verzeichniss einer Wohllöblichen Kaufmannschaft nach alphabetischer Ordnung und Bemerkung der Reception nebst einem Anhange der vorzüglichen Fabriken im Jahre 1818 (Breslau, 1818), specifying 370 Christian entrepreneurs, of whom $100(28 \%)$ were registered before 1800, $259(72 \%)$ in 1800-18, incl. 146 (as many as 40\%) between 1810 and 1818: these numbers well represent the dynamism with which Christian merchantry developed. A list of Jewish merchants is attached at the end, specifying 97 names, with 14 bankers among them. Such lists were probably printed annually; one more, from 1843, survives: Verzeichniss sämtlicher, added to which is a list of nicht-recipierte Kaufleute naming 482 unregistered merchants (against 271 registered). The press moreover discusses a 1841 list; cf. Allgemeine Zeitung des Judenthums, v (1841), no. 36, 507. These lists have not been penetratingly analysed yet. 
The new statutes normally abolished the old organisations and established new ones to replace them, to be led by 'merchantry elders' (Älteste der Kaufmannschaft, mostly Christians) and to consist of members with, virtually, no religion-related restrictions (thus, Jews were taken into account). ${ }^{73}$ Such new organisations were set up in the 1820 s - in Berlin, Stettin, Danzig, Memel, Königsberg, Tilsit, Elbing, and Magdeburg. ${ }^{74}$ The new regulations enabled to integrate the trade and elaborate a common policy to respond to the fast-changing markets.

In the first half of the nineteenth century, the situation in Breslau was different compared to the other Prussian cities or towns. Large immigrations of Jews from Eastern Europe and the fast-attained high position of Jewish bourgeoisie were perceived by the Christian merchant elite as a threat. The situation was rooted in the preceding centuries. With the progressing Jewish settlement in Silesia and privileges that extended also to Polish Jews, they faced growing reluctance from Christians. The seventeenth century saw the first such conflicts, initially targeted at the native Jews; soon after, complaints extended to Polish Jews as well. ${ }^{75}$ The patricians and the city council dominated by them strove to limit the settlement and privileges enjoyed by Jews. They achieved partial victory in 1702, when the Law for Jews (Judenordnung) was adopted. ${ }^{76} \mathrm{~A}$ particular reluctance toward Jews manifested itself in the 1730s, leading to the passing in 1738 by Emperor Charles VI of the instruction for 'unprivileged' Jews to leave Silesia. After Silesia was seized by Prussia in 1740, this policy was initially continued. The privileges granted to Jewish people by Frederick II caused intensification of accusations coming from Christian merchants against

${ }^{73}$ Martin Will, Selbstverwaltung der Wirtschaft. Recht und Geschichte der Selbstverwaltung in den Industrie- und Handelskammern, Handwerksinnungen, Kreishandwerkerschaften, Handwerkskammern und Landwirtschaftskammern (Tübingen, 2010), 269. Cf., for instance, the Statute of a new corporation in Stettin: 'Statut für die Kaufmannschaft von Stettin 15.11.1821', in Gesetz-Sammlung für die Königlich-Preußischen Staaten 1821, no. 18, $272 \mathrm{ff}$. III Abschnitt [section], $\mathbb{\$} 9$ state than neither the sex nor the religion shall be of relevance as far as joining the corporation is concerned (Polish and German versions: //www.wbc.poznan.pl/dlibra/publication/487239?tab=1).

${ }^{74}$ Clemens Wischermann and Anne Nieberding, Die institutionelle Revolution: eine Einführung in die deutsche Wirtschaftsgeschichte des 19. und frühen 20. Jahrhunderts (Stuttgart, 2004), 132.

${ }^{75}$ Rabin, Beiträge zur Rechts- und Wirtschaftsgeschichte, 41-2.

${ }^{76}$ Brilling, Geschichte der Juden in Breslau von 1454 bis 1702, 29-32; Agethen, 'Die Situation der jüdischen', 313. 
Jews. ${ }^{77}$ It was insinuated that Jews had brought about ruination of local merchant families, ${ }^{78}$ and it was demanded that the Jewish population be reduced and the Schammeses banned. ${ }^{79}$ The 1812 Emancipation Edict that cancelled all the privileges bestowed upon Jews made the conflict even more severe.

After 1812, the opportunities for settlement in urban as well as rural areas, unlimited by restrictive regulations, and for commercial, banking, and craft activities implied fast expansion and economic advancement of the Jewish people. One good example is the history of a banking house run by Ernst Heimann, which in the 1830s became a significant enterprise among Silesian banks - thanks to its deals with merchants from former Polish territories, among other things. ${ }^{80}$ Breslau commerce was unable to develop and export goods to the East without the intermediation of Jewish wholesale merchants and bankers. In his recapitulation of the history of Silesian trade (published in 1924), Wendt stressed that trading with Poland would have been hardly conceivable without the agency of Jews. ${ }^{81}$ Thus, interests spoke in favour of having Jewish in the ranks of merchant organisations. Still, concerns were raised about competition on their part, as Jews did know the Eastern market and had numerous contacts with Polish merchants; moreover, their importance, economic as well as political, was on the rise. Therefore, members of the merchant corporation tried to retain its previous structure in order to ensure the restriction of the rights of their Jewish competitors. In the first decades of the nineteenth century, this dichotomy led to a deadlock in the Christian-Jewish relations - characterised, as they were, by mutual dislike, exacerbating prejudices and, above all, resistance among the Christians against admitting Jews to modern commercial and business institutions, stock exchange included.

77 Arno Herzig, 900 Jahre jüdisches Leben in Schlesien (Görlitz, 2018), 79-81.

${ }^{78}$ Agethen, 'Die Situation der jüdischen', 319.

${ }^{79}$ For an extensive account on Christian merchants' actions against the Jews in the Prussian time (until 1811), see Scholz, Die wirtschaftspolitische Tätigkeit, 45-50; also, Rabin, Beiträge zur Rechts- und Wirtschaftsgeschichte, 52; Herzig, 900 Jahre, 53-6.

${ }^{80}$ Schneider, E. Heimann; Afeltowicz, Studia nad historia.

${ }^{81}$ Heinrich Wendt, 'Die kaufmännische Standesvertretung in Breslau vor Begründung der Handelskammer', in Freymark, Die Handelskammer, 341-2; Wilhelm Treue, Wirtschafts- und Technikgeschichte Preußens (Veröffentlichungen der Historischen Kommission zu Berlin, 56 (Berlin, 1984), 55 ff., 118 ff. 
III

\section{CHRISTIAN MERCHANTS ENDEAVOURING TO KEEP UP THEIR POSITION AMONG MERCHANT ELITES}

The merchants' guild was established in $1339 .{ }^{82}$ Since the early eighteenth century, it assumed the name of Collegium Mercatorum. ${ }^{83}$ The organisation was initially joined by wholesale merchants doing their business at the cloth hall. Retailers were associated with the Rich-Stalls (Reichkrämer) Merchants' Corporation; in 1820, they dissolved their association and some of them joined the merchant corporation. ${ }^{84}$ In 1805, 173 merchants appointed forty-nine non-merchants - mainly lawyers and physicians - members of their organisation, established as the Merchants' Club (Kaufmännische Ressource) with a statute of its own. ${ }^{85}$ Resulting from disagreements between the Club and the merchants, ${ }^{86}$ it was resolved in 1819 that the two organisations would be merged into a 'Newly-Established Merchants' Club' (Neu errichtete kaufmännische Ressource), which absorbed the registered merchants (recipierte Kaufleute) from the merchant corporation and, as it was emphasised, almost all the Club members other than merchants. ${ }^{87}$ The

${ }^{82}$ Wendt, 'Die kaufmännische Standesvertretung', 327-59.

${ }^{83}$ Heinrich Wendt, Das erste Jahrhundert der Kaufmännischen Zwinger- und RessourcenGesellschaft in Breslau 1805-1905. Festschrift zum Jubelfeier (Breslau, 1905), 6-7. The guild was also known as the 'Kaufmannschaft zu Breslau' or 'Die kaufmännische Korporation zu Breslau'; these names were used when turning the organisation into a 'Verein christlicher Kaufleute' in 1859; cf. Außerordentliche Beilage zu No. 28 des Amts-Blattes des Königlichen Regierung zu Breslau pro 1859, 171; the statute of the new association, 171-6 (http://opacplus.bsb-muenchen.de/title/4104033/ft/ bsb10001197? page $=193$ [Accessed: 10 Aug. 2019].

${ }^{84}$ On merchants of the Rich Stalls, see Tagmann, 'Zur Geschichte der ReichkramerSocietät in Breslau', in Jahresbericht des Schlesischen Gesellschaft für Vaterländische Cultur, xxxii (1855), 223-43; for a polemic article, see Theodor Oelsner, 'Die ehemaligen Reichkramer im Breslauer Gemeinde-Organismus', in Monatsschrift für preußisches Städtewesen, ii (1856), 516-23; also, Julius Neugebauer, 'Vortrag', in Jahresbericht des kaufmännischen Vereins pro 1861 (Breslau, 1861). For the relationship between the two merchant associations in 1670-1847, see APWr, 'Archiwum Giełdy Kupieckiej', ref. no. 82-304-0-562.

${ }^{85}$ Wendt, Das erste Jahrhundert (for a complete history of the organisation).

${ }^{86}$ Ibidem, $12 \mathrm{ff}$.

${ }^{87}$ Files concerning the period between 1819 and 1831 in APWr, 'Archiwum Giełdy Kupieckiej', ref. nos. 82-304-0-564 and 82-304-0-565. For interesting records on the registration of merchants (recipierte Kaufleute) from 1771-1857, see APWr, 'Archiwum Giełdy Kupieckiej', ref. nos. 82-304-0-551 to 82-304-0-559. 
new association took over all the former merchants' privileges, primarily the option to trade at stock exchange, and their assets, with equities estimated at 200,000 thalers. Added to that were valuable realties, such as the Zwinger building, with a grand ballroom and a large garden, situated in the city's centre, at the promenade, and a complex of buildings at one of the city's central squares (named today Solny Square), which housed an Exchange since the seventeenth century. ${ }^{88}$ The association managed the city's river port. It was not easy to be admitted to this elitist organisation; in 1822 the Merchants' Club had only 249 members. ${ }^{89}$

It might be argued that the merger of the merchant organisations and creating a new entity was part of the trend observable in Prussia at that time. However, Jews were excluded from the new organisation in Breslau, which was an exceptional fact. It was already in 1809-10, 1815 and 1821 that the provincial authorities tried to inspire a transformation of the old merchant institutions and recommended to establish a new organisation that would accept Jewish members. ${ }^{90}$ The Breslau corporation strongly opposed the idea, though; apart from membership in the Protestant or Catholic Church, the condition of admittance was apprenticeship with a Christian merchant. The organisation wanted to be a monopolist importer and exporter of goods. The new Merchants' Club therefore claimed the right to be a regulator of all the business affairs in the city. As a Christian association, it brought together the city's elite of the time; with its considerable wealth, it was pretty influential; soon, the city's most showy edifice was to become part of its assets.

Designed by the then-most outstanding Breslau's architect Carl Ferdinand Langhans, the building was erected by the Neuerrichtete Kaufmännische Ressource in 1825, at what is today 16 Solny Square ${ }^{91}$ (Figs 1,2). The building had a double role: the ground-floor housed the stock exchange rooms, and hence the building was colloquially

${ }^{88}$ The buildings in today's Szajnochy St. and the former Rehdiger Palace at Solny Sq.

${ }^{89}$ Wendt, Das erste Jahrhundert, 13.

${ }^{90}$ Allgemeine Zeitung des Judenthums, vii, 40 (1843), 599; Schneider, E.Heimann, 84-5; Walter Henschel, Die Börse in Breslau: Inauguraldissertation zur Erlangung der Doktorwürde der rechts- und staatswissenschaftlichen Fakultät der Schles. Friedrich-WilhelmsUniversität zu Breslau (Breslau, 1933), 16-17.

91 Zabłocka-Kos, Zrozumieć miasto, 94-109. 


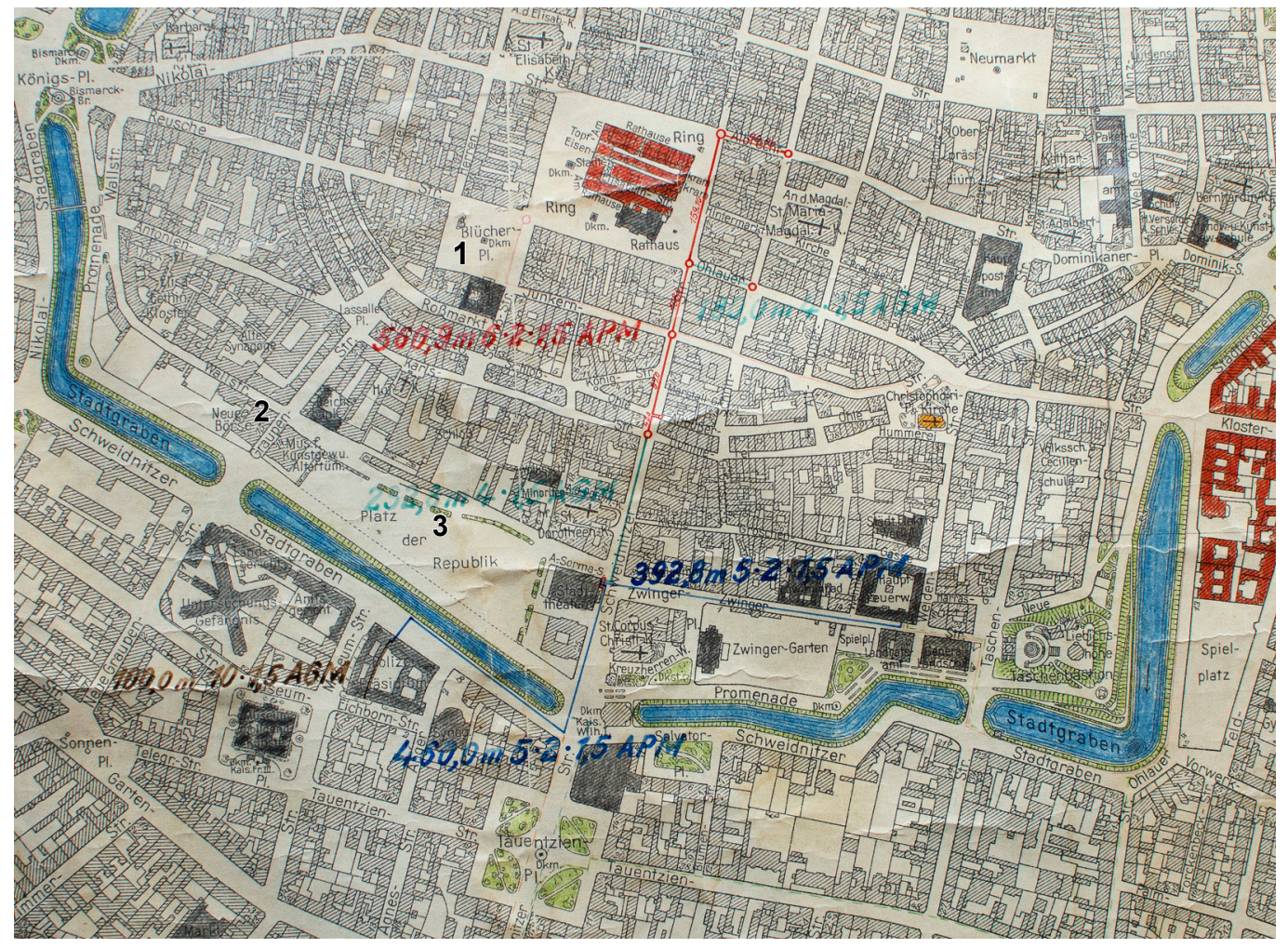

Fig. 1. Plan of Breslau of 1935. 1. Old Exchange of 1825, Solny Place 16 (Blücherpl.16), 2. New

Exchange of 1867, Krupnicza 15 (Graupenstr.15), 3. Royal Forum - the 40s of 19th c. Private collection 


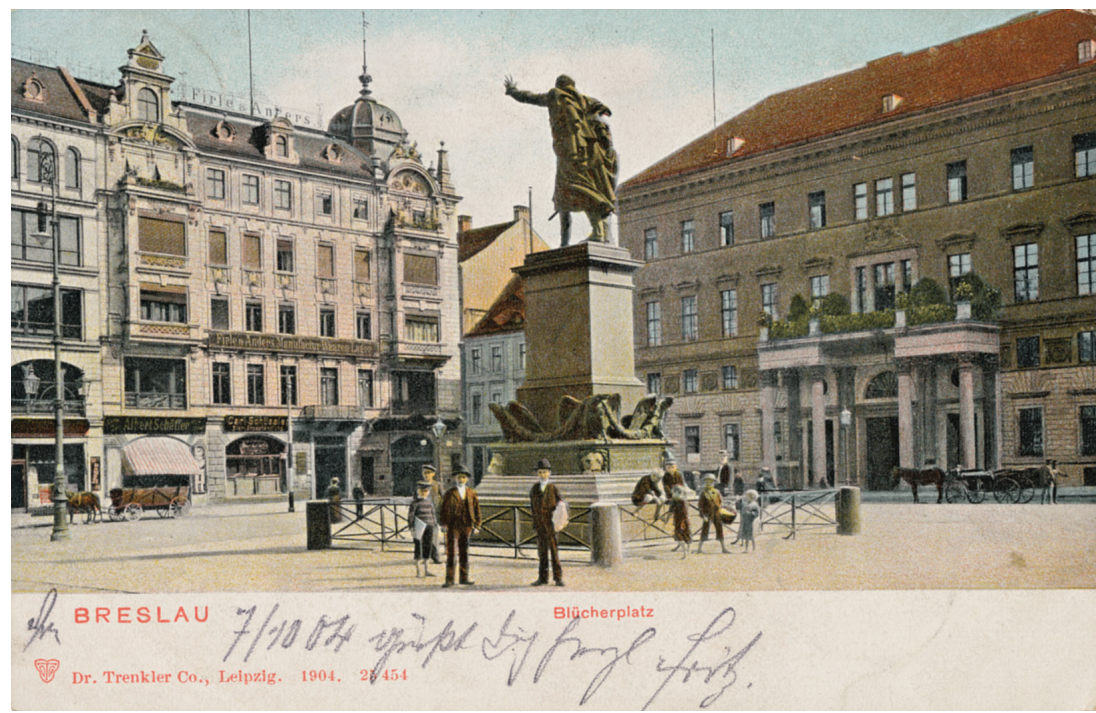

Fig. 2. View of the Old Exchange (on the right) and of Feld-marshal Blücher's. Dr. Trenkler's postcard, Leipzig, 1904. Mariusz Kotkowski's private collection

named 'the Exchange'; fundamentally, though, it was a venue of social life. The magnificent first-floor rooms set the scene for concerts, balls, diverse meetings, and exhibitions. These palace-like interiors invited local Protestant and Catholic elites - the crème of Breslau's bourgeoisie and nobility - over dozens of years. ${ }^{92}$ Being the most beautiful and most frequently visited (along with the local theatre) public-utility building in the Silesian capital, the Club marked a poignant exclusion of townsmen of Jewish descent..$^{93}$

They insisted that the merchant corporation accept them as members, but the organisation strove to defend its unique position, as far as possible ${ }^{94}$ - also as the monopolist exchange manager. The Exchange was set up in Breslau in 1603 - initially as a commodity

92 Wendt, Das erste Jahrhundert, 14-16.

93 The first ball at the exchange which Jews were allowed to attend was held only in 1870; cf. Jacob Toury, Soziale und politische Geschichte der Juden in Deutschland: 1847-1871; zwischen Revolution, Reaktion u. Emanzipation (Düsseldorf, 1977), 128. Toury also points to press articles regarding the boycott of Jews in Breslau; cf. remarks on this subject made from the Jewish perspective in Schreiber, E. Heimann, 15.

94 Wendt, Das erste Jahrhundert, 20. 
exchange; 1670 saw the adoption of the statute of brokers. ${ }^{95}$ Toward the end of the eighteenth century, the commodity exchange turned into a monetary exchange, with an increasing role of securities, debt securities, stocks, bonds or debentures, bills-of-exchange, etc. Participation in stock exchange operations was associated with access to European markets, practicing commercial activities, and cash trading on a large scale. Hence, in 1834, Jewish entrepreneurs, led by the banker Ernst Heimann, attempted at forming a common stock exchange; however, the project ended up in failure. ${ }^{96}$ In 1837 , at a session of the Silesian Provincial Parliament, a draft of the new governmental 'Procedural Police Law' (Allgemeines Gewerbe-Polizei-Gesetz) was put forth. The Christian merchants considered it dangerous to their privileges and influential power; they expected that the corporation might be doomed to dissolution, its assets and property transferred or liquidated. ${ }^{97}$ In the face of such threat, a new statute was adopted in 1839 (which remained in force until 1895), sanctioning the formation of a new Merchants' Zwinger and Club Association (Kaufmännische Zwinger- und Ressourcengesellschaft) and reconfirming the rule of admitting Christians only. The members were split into merchants with the right to hold the association's estate and non-merchants. Thereby, a possible loss especially, of any real property - was prevented. Under the replaced statute, the association could manage its assets on its own and hold the Zwinger and the Exchange and Club building in Solny Square on an exclusive basis. ${ }^{98}$

It was emphasised that "This association, previously low-keyed, and completely independent of the Merchants' Club, now held the corporative rights and ability to acquire assets on its own. Whilst merely using the Club's premises so far, it was now to take-over its estate and, thence, become the proprietor of the Exchange and the Zwinger". ${ }^{99}$

${ }^{95}$ Ibidem, 7; Harasimowicz, Encyklopedia Wroctawia, 224.

${ }^{96}$ Schneider, E. Heimann, 52.

97 Wendt, Das erste Jahrhundert, 20; Roland Gehrke, Landtag und Öffentlichkeit. Provinzialständischer Parlamentarismus in Schlesien 1825/1845. (Neue Forschungen zur Schlesischen Geschichte, Bd. 17) (Köln, Weimar and Wien, 2009), 225. On the Judenfrage addressed at a parliamentary session, 249-55.

98 Wendt, Das erste Jahrhundert, 21; files from the years 1846-9: APWr, 'Archiwum Giełdy Kupieckiej', ref. nos. 82-304-0-570 and 82-304-0-571.

99 Wendt, Das erste Jahrhundert, 21. 
The period between the announcement of the Emancipation Edict of 1812 and Frederick William IV's coming to the throne in 1840 was marked, in Breslau, with the conflict between the Christian economic elite and its Jewish counterpart. The endeavours made by the Jews to bring about complete equality did not produce satisfying results. ${ }^{100}$ A new era only opened with the reign of Frederick William IV.

\section{IV \\ BRESLAU'S CHAMBER OF COMMERCE FORMED AND ESTABLISHED, 1848}

The hope for a 'new opening' was incited by the king's first visit to Breslau, in $1841,{ }^{101}$ and by the cabinet instruction of 13 December 1841, regarding as follows: "Anerkennung jener religiösen und nationalen Einheit und desjenigen Sonderbetriebes der Juden in den christlichen Länder, der davon die natürliche Folge ist". The king recommended that Jews form corporative associations with legal personality, which would enable them to function on a par with the similar Christian unions. The emergence of such homogenous associations, called Judenschaften, was particularly difficult, owing to a dispute between the liberal and the conservative party within the Jewish community itself. ${ }^{102}$

Encouraged by these positive signals, Breslavian Jews requested the Minister of Commerce (twice, on 13 June 1841 and again on 19 January 1842) to take action to sort out the relations between Christian and Jewish merchants. ${ }^{103}$ The central conflict concerned the use of the

${ }^{100}$ Roland Gehrke, 'Zwischen Diskriminierung und Emanzipation. Die „bürgerlichen Verhältnisse der Juden“ als Verhandlungsgegenstand der schlesischen Provinziallandtage (1825-1847)', in Brämer, Jüdisches Leben, 31-59. For an exhaustive discussion of the effects of putting the Edict into practice, see Ziątkowski, Między niemożliwym a koniecznym.

${ }^{101}$ Attempts were initially made to prevent the meeting between representatives of the Jewish community and the monarch, but it was finally held, and twelve representatives were appointed among the Jews; see Allgemeine Zeitung des Judenthums, v (1841), no. 36, 506-9, here 508. On the king's visit see: Allgemeine Zeitung des Judenthums, v, 41 (1841), 577-8. Cf. Erich Fink, Geschichte der landesherrlichen Besuche in Breslau (Breslau, 1897), 167-76, here 173-4.

102 Gehrke, Landtag und Öffentlichkeit, 330-7; Gehrke, 'Zwischen Diskriminierung', 48.

${ }^{103}$ For excellent documentation of the process of organisation of the Chamber of Commerce, see the files of the Municipality of Breslau from the years 1820-47: APWr, 
Exchange, especially that as of 1843, 482 unregistered merchants were listed, against 271 registered ones. ${ }^{104}$ Following a lengthy bargaining process, in 1843, Christian merchants admitted non-associated merchants to using the Exchange premises at Solny Square (for the fee of 3 thalers). While this was interpreted as the start proper of a modern stock exchange, the mutual relationships were continuously marked by incessant conflict. ${ }^{105}$

Participation in stock exchange operations was fundamental at that time to doing commercial and banking business. With the development of railway and other industries, the role of capital and securities market was growing. ${ }^{106}$ Prevention of stock exchange transactions excluded a group of extremely active entrepreneurs and bankers from economic development. Therefore, their negotiations in view of transforming the old corporation into a common organisation were a must for a number of Jewish interests to survive and, possibly, develop. The bargaining led to no positive outcome, though: Christian members of the merchant corporation declared that they would rather prefer to waive their statutory rights and powers than consent to a restructuring and real change. ${ }^{107}$ The wrestle for setting up an organisation that would be representative of Christian as well as Jewish merchants intensified in the $1840 \mathrm{~s},{ }^{108}$ the main actors being, on the Christian merchants' side, Theodor Molinari (registered merchant since 1829), Johann Ferdinand Kracker/Königl. Commerzien- und Conferenzrath (registered since 1815), and Friedrich Eduard Loebbecke/Geheimer Commerzienrath,

'Akta Miasta Wrocławia', ref. no. 28-0-30466; here, esp. a letter from representatives of Jewish merchants to the Minister of Commerce, dated 2 May 1844 and signed by Jonas Fränckl, Joseph Leipziger, Wilhelm Friedenthal, Bernhard Primker, Louis Dyhrenfurth, Ernst Heimann, M. Schreiber, and Moritz Landsberger, concerning the Exchange affairs and the statute of the future common merchant corporation; APWr, 'Akta Miasta Wrocławia', ref. no. 28-0-30466, 81-4.

104 Verzeichniss sämtlicher, with an additional list of nicht-recipierte Kaufleute attached; Henschel, Die Börse, 16. Cf. An extensive article on the relationship between Christian and Jewish merchants in Allgemeine Zeitung des Judenthums, v, 36 (1841), 506-9.

105 Henschel, Die Börse, 17-18.

106 For an exhaustive account of the development of Breslau's banks, see Afeltowicz, Studia nad historia, 78-86.

${ }^{107}$ Freymark, Die Handelskammer, 14.

108 As excellently illustrated by the files in APWr, 'Akta Miasta Wrocławia', ref. no. 28-0-30466. Also, cf. APWr, 'Archiwum Giełdy Kupieckiej', ref. nos. 82-304-0-357 and 82-304-0-182, 82-304-0-183; petitions to the Landtag, ref. no. 82-304-0-450. 
a banker (registered since 1824); the Jewish party was represented Jonas Fränckel/Königl. Commerzienrath, Louis Dyhrenfurth, and Letzfeld. ${ }^{109}$ With active involvement of representatives of the Municipality, Regency, and the Presidium of the Police, a common commission was established and work began, in 1843, on the future organisation's statute. In spite, however, of numerous meetings held and a positive attitude on the part of Municipality members, arriving at a shared position proved impossible - one bone of contention having been the setting of the proportion for Christian merchants and Jews to be represented within the organisation.

The dispute and discussions over the shape of the intended organisation of merchants lasted into 1848 and were interrupted by the announcement, on 11 February 1848, of the law on establishment of Chambers of Commerce in Prussia. ${ }^{110}$ Thenceforth, members of the Chamber were to be elected among tax-paying artisans, merchants, industrialists, and bankers - altogether, the most influential personages among the economic elite. The Chamber would organise the commercial life in the city, its tasks including the running and supervision of stock exchanges. Establishment of such chambers was meant not only to ensure efficient functioning of trade and commerce: what it moreover did was it enabled for Jews access to commercial operations on equal terms with Christians. Chambers of commerce became the most important merchant organisations: not eliminating the previously functioning corporations, they did limit their influence.

The chamber-of-commerce law intensified the activity of Breslau's Jewish merchants who feared that their milieu might be boycotted again when it came to establishing a new, intentionally 'non-denominational' (religion-neutral), organisation. Soon, on 28 February 1848, bankers Ernst Heimann and Marcus Nelke, together with thirty-two nonregistered merchants, sent a letter to registered merchants, stressing that it was impossible to use Exchange rooms at Solny Square or participate in Exchange sessions (Börsenversammlung); they moreover

109 APWr, 'Akta Miasta Wrocławia', ref. no. 28-0-30466, 3-8. Cf. Verzeichniss sämtlicher (1843), 12-14.

110 'Verordnung über die Errichtung der Handelskammer vom 11.02.1848', in Gesetz-Sammlung für die Königlichen Preußischen Staaten (1848), no. 7, 88-96 (German and Polish version: http://www.wbc.poznan.pl/dlibra/publication?id=496153\&tab $=3$ [Accessed: 10 Aug. 2019]. Cf. Will, Selbstverwaltung der Wirtschaft, 275-9. 
pointed to the need to form a homogenous merchants' organisation. ${ }^{111}$ This ferment in the circle of industrial and economic elites led to the formation, on 30 March 1848, of a temporary Chamber of Commerce, ${ }^{112}$ which was finally approved on 15 June $1848 .{ }^{113}$

The dispute was not resolved, though. Although a Chamber of Commerce was set up in the city of Breslau, the Kaufmännische Zwinger- und Ressourcengesellschaft - inheritor of the Collegium Mercatorum - existed alongside it, running the Exchange. For the Chamber to legally act, the corporation should have got dissolved and transfer all its rights to the Chamber, or been incorporated by the Chamber in its entirety, together with the Exchange-managing privileges. However, the Christian merchants would not renounce their prerogatives. As a result, a pamphlet was published in October 1848 discussing the revision of the statute of the provisional Chamber of Commerce; it read,

Reviewing the statutes of the existing corporations has, therefore, been an indispensable, statutorily-driven necessity exercised in public-and-legal interest. This was primarily pertinent to the provisions whereby, in actual fact - as was the case with the Code of this Corporation of Christian merchants - there existed the like confession-related restrictions in admitting members, which unceasingly caused numerous inconveniences. As far as is known, the merchant Corporation hereof does not even have a decent statute, whilst its Code, as to its major principles, is mostly founded upon observances and the unordered status quo. ... the further existence of the Corporation of Christian merchants hereof, based upon its old and nonreviewed statutes, is, therefore, an anomaly that is at odds with the public order established by the law; this is an anomaly also from the view-point of the elder state-law, which acknowledged the equality of all the citizens

111 The letter is quoted, in its entirety, in Hentschel, Die Börse, 19-20.

112 Ysselstein, Lokal-Statistik, 121.

113 Individuals being indisputably the leading authorities among Christian merchants were elected chairman and his deputy - namely, Theodor Molinari and Karl August Milde, both of Catholic religion. Sitting on the founding committee were moreover E. Credner, L.T. Eichborn, F. Klocke, C.G. Kopisch, G. Liebich, C.F. Poser, B. Beyersdorf, D. Gordan, F.W. Grund, L. Heyne, J. Hoffmann, B. Lasswitz, H. A. Schneider, along with influential exponents of the Jewish milieu: Ernst Heimann, Wilhelm Friedenthal, S. Goldschmidt, Moritz Landsberger, B. Lasker, Moritz Schreiber, D. Immerwahr, and E. Wortmann, some of whom had previously taken part in the discussions on the Breslau commerce. See Freymark, Die Handelskammer, 14-16. 
only, and exclusively, in the private-law cases - let alone in the light of the principles of the contemporary conception of state which guarantees identical political rights to all, without an exception. ... Not only does any further existence of the old Club of Christian merchants in the unchanged form stand, as has been demonstrated, in plain contradiction to the letter of the law, whilst also being an instance of direct restriction of the rights of all the other professional groups; it, moreover, poses an obstacle for them to enforce the competencies otherwise ensured to them by the Law.... Putting aside the fact that the old, unrevised statute excludes a considerable number of merchants from being admitted in the Corporation, the existence of the present Corporation prevents them from establishing a new and autonomous corporative association. ${ }^{114}$

The formation of the appropriate Chamber of Commerce, with both Christian and Jewish members of the its management board, took more than a year thereafter; the Chamber was eventually set up on 30 May $1849^{115}$ and was mainly tasked with managing and supervising the Exchange, determining the exchange rates, contacts with other exchanges/stock exchanges, etc. - which in practice meant controlling the trade in its entirety. ${ }^{116}$ Thus, an organisation emerged in Breslau whose task was to set in order and supervise the affairs of economy and to create a place for interpersonal relations and professional contacts that would be free of the ballast of religious identification and exclusion. How tense the situation was is attested by the emergence, in 1856, of a Union of Catholic Merchants (Verein katholischer Kaufleute): clearly, there was no unity even among the Christian merchant community. One attempt at uniting the minds and attitudes was the reorganisation, in 1858, of the Kaufmännische Zwinger- und Ressourcengesellschaft into a Christian Merchants' Society [Verein christlicher Kaufleute). The new entity obtained legal personality and held the proprietorship of all the previous real estates, assets, and

114 Über die nothwendige Umgestaltung der hiesigen kaufmännischen Corporationsverhältnisse, Denkschrift der erwählten Commission nicht-recipierte Kaufleute als Vorlage $z u$ den Conferenzen mit dem Deputierten der Corporation. 1848 Okt 18 (Breslau, 1848) (underlined as in the original).

${ }^{115}$ In May 1849, after yet another election, the final Chamber of Commerce was set up, composed of Theodor Molinari, F. Klocke, J.A. Franck, C. Credner, Joseph Hoffmann, C. Milde, B. Lasker, M. Landsberger, Dr Friedenthal, S. Goldschmidt, J. Friedenthal, G. Liebich, E. Heimann, and C. Krull. See Freymark, Die Handelskammer, 15. Those men played afterwards a leading role in the construction of the Exchange edifice.

${ }^{116}$ Freymark, Die Handelskammer, 16-17. 
foundations; ${ }^{117}$ total assets at the time were estimated at half a million thalers. ${ }^{118}$ The emergence of the Christian Merchants' Society put an end to a stage in the Christian-Jewish dispute in Breslau. Thereby, the heirs of the Collegium Mercatorum officially relinquished their influence on the Silesian capital city's economic landscape. They could do it, since their impact on the operations of the Chamber of Commerce, whose role was now decisive in the city's economic life, had been decisive over the preceding decade.

\section{$\mathrm{V}$ \\ NEW EXCHANGE AS A TRADE-OFF CONCLUSION OF THE CHRISTIAN-JEWISH DISPUTE}

The emergence of the Chamber of Commerce marked a milestone in the regularisation of the commercial relationships in Breslau. It did not, however, resolve the most burning issue of use by unregistered merchants of the Exchange premises at 16 Solny Square, as the property was continuously owned by the corporation of Christian merchants. True, the institution was opened in 1843 also for the Jews, but the multiple disputes between the Christian and Jewish users led in 1851 to an attempt to create an independent Jewish exchange. The Assembly of Jewish Merchants (Versammlung der jüdischen Kaufleute) ${ }^{119}$

${ }^{117}$ For a minute history of the Verein der christlichen Kaufleute, see Ysselstein, Lokal-Statistik, 124-6. It is significant that in 1866, when the disputes between merchants were still fresh, the association was dealt with a great deal in the first edition of the extensive and content-wise diverse statistics of Breslau. Also, cf. Schlesische Provinzialblätter Neue Folge, v (1866), 718-20; Wendt, Das erste Jahrhundert, 22.

118 Built in a palace style and enjoying the prestigious location at 16 Solny Sq., by the road leading to the Royal Palace, the Club was valued at 112,000 thalers (according to a contemporary appraisal report). Appraisal report of 28 May 1859, in APWr, 'Archiwum Giełdy Kupieckiej', ref. no. 82-304-0-93, 617. The other assets included (among other items) the magnificent Zwinger with a garden integrated into the city promenade (worth 25,000 thalers), the Packhof (city port, 105,000 thalers), and the Selenkesche Institut (25,000 thalers). The union managed a total of twenty-four foundations. The statistics is quoted after an article in Schlesische Provinzialblätter Neue Folge, v (1866), 718-20, here 719. For a detailed listing of the assets and foundations, see Ysselstein, Lokal-Statistik, 127-30. The Zwinger became property of the merchant corporation in 1813. Also, cf. Julius Neugebauer, Der Zwingerund die kaufmännische Zwingerschützen-Brüderschaft (Breslau 1876), 79.

${ }^{119}$ As stressed by Henschel, the nichtrezipierte Kaufleute were identified by the period's press with merchants of Mosaic religion (Henschel, Die Börse, 21), which 
decided that as from 5 May 1851 onwards, these merchants would not participate in trading sessions held at 16 Solny Square, and would meet on a daily basis at 52 Market Square instead. "These meetings may be attended by literally anybody who deals with commerce and business, provided that he has declared that he only would participate in these very assemblies, rather than those at the Exchange premises [i.e. at Solny Square]". ${ }^{120}$ Thus, Breslau eventually saw the emergence of two exchanges - an occurrence that was referred to as a "exchange schism'. ${ }^{121}$ Given the tense situation, the Chamber of Commerce took decisive action and the shared stock exchange, as the Chamber's venture, was moved on 1 July to a large space at the Cafe Restaurant, in direct vicinity of the Royal Palace. Still, the location was perceived as temporary and unworthy of the merchant class. ${ }^{122}$

Hence, purchase of a plot of land for the future residence of the Chamber became a priority for this institution at the early stage of its activity. Apart from trading space, it was to house office premises as well. The financial surpluses gained from exchange entry fees were used to buy, in as early as 1853 , a land with the intent to erect a Chamber building together with stock exchange's trading premises. ${ }^{123}$ The allotment was situated in a very attractive area of the city, right near the promenade constructed in the early nineteenth century in place of the former fortification. The Royal Palace stood close to it, along with the stately Silesian Parliament (Ständehaus) edifice and the Royal Court and Prison assembly; these buildings were part of the Royal Forum complex ${ }^{124}$ (see Fig. 1). Finally, it was decided in 1853 that

is not completely true. The Allgemeine Zeitung des Judenthums minutely analyses the 1841 list of merchants. While the section on registered merchants, specifying 256 names, raises no doubt, the one spacifying non-registered merchants has 553 names - among them, 249 Christian merchants who had not been registered (for some reason or another), and 304 Jewish ones. Cf. Allgemeine Zeitung des Judenthums, v, 36 (1841), 507.

${ }^{120}$ Henschel, Die Börse, 21.

${ }^{121}$ Ibidem, 22.

122 In today's Kazimierza Wielkiego St. (Karlstr. 37; not surviving).

${ }^{123}$ The allotment at Wallstr. 6 (today's P. Włodkowica St., official address 15 Krupnicza St.) was owned at the time by Count Hochberg-Fürstenstein; Rabbi Tiktin's widow dwelled there. Cf. Adressbuch der Haupt- und Residenzstadt Breslau für das Jahr 1852 (Breslau, 1852), 147; Freymark, Die Handelskammer, 27; Henschel, Die Börse, 25.

${ }^{124}$ For a detailed discussion on the emergence and importance of the Royal Forum, see Zabłocka-Kos, Zrozumieć miasto, 229-55; ead., 'Friedrich Wilhelm IV. 
a 'non-denominational exchange' be built in a prestigious location. The Chamber's annual report for the year 1854 highlighted that a piece of land had been acquired and the associated merchants hoped for the construction works to commence in $1855 .{ }^{125}$ Initial conception work was undertaken and first designs prepared - by Hermann Friedrich Waesemann, a young architect, then on an assignment in Breslau, where he designed a magnificent villa for the banker Moriz-Eichborn and his family. ${ }^{126}$

However, it was only the formation, in 1858, of the Verein der christlichen Kaufleute that paved the way for the construction of a new residence of the Chamber of Commerce. After a series of hardships, in the year 1863 - ten years after the piece of land was purchased Johann August Franck managed to set up a joint-stock company named 'Breslavian Exchange Stock Union' (Breslauer Börsen-Aktien-Verein): a legal personality that became the chief investor for the project of importance to the city and the region. Franck was one of the most active representatives of the bourgeoisie: a commercial counsel and a banker, member of the City council, and the Provincial Parliament, he was, above all, President of the Chamber of Commerce in 1861-9. ${ }^{127}$

und die Gestaltung des Schloßplatzes in Breslau', in Generaldirektion der Stiftung Preußischer Schlösser und Gärten Berlin-Brandenburg (ed.), Friedrich Wilhelm IV Künstler und König (Frankfurt am Main, 1995), 150-7.

125 Jahresbericht der Handelskammer (1855), 16.

${ }^{126}$ Designer of Berlin's Town Hall and contestant for the design of the Exchange building in Berlin, Waesemann [Wäsemann] worked in Breslau in 1853-6 as a Landbaumeister; see Anna Bober, 'Wrocławska willa Eichborn i jej motywy antyczne', in Zofia Ostrowska-Kęblowska (ed.), Dylematy klasycyzmu. O sztuce Wroctawia XVIIIXIX wieku $i$ jej europejskich kontekstach (Wrocław, 1994), 163-90. A drawing of the situation plan of the new Exchange, kept at the Technische Universität Berlin, 'Architekturmuseum Plansammlung', ref. no. 6691, features his signature (https:// architekturmuseum.ub.tu-berlin.de/index.php? $\mathrm{p}=51 \&$ SID $=15478130026561)$.

${ }^{127}$ Freymark, Die Handelskammer, 48. Johann August Franck (b. 8 Aug. 1805 in Breslau, d. 11 Oct. 1878) was a Protestant, member of St. Elisabeth's parish; resided at 10 Solny Sq. (owning the entire house). Buried at St Nicholas's Cemetery in what is Legnicka St. now (not surviving today). A banker, Franck managed the bank founded by his father (until 1859), was a secret commercial counsel, member of the Silesian Landtag, member (since 1849) of the Chamber of Commerce and its chairman in 1861-9; city councillor with the Municipality and councillor with the City Council and the Financial Deputation, Curator with the City Bank [Stadtbank], the 'Elder' with the Christian Merchants' Society [Ältester des Vereins christlicher Kaufleute], founder and long-time President of Schlesischer Bankverein, cofounder and Head of the Verwaltungsrath Oberschlesische Eisenbahngesellschaft, member 
The company's statute, approved by the king and by the Minister of Commerce (on 3 July and 9 August 1864, respectively) defined (in Para.2) its purpose described as the construction of an exchange building that would include office space and apartments for the officials. A capital of 150,000 thalers, to be amassed through the sale of shares, was earmarked for the project. ${ }^{128}$ The company was established for fifty years to be dissolved afterward. Among its responsibilities was to oversee the construction process, which meant to select the best-fitting design and keep watch over the building once built. The Board was formed of five representatives of Christian merchants, with Franck as the chairman, the members being Theodor Molinari, commercial counsel; Heinrich Korn, city councillor; Rudolph Schöller, industrialist; - plus seven of the Jewish community: Isidor Friedenthal, Robert Caro, Löbel Guttentag (a banker), Wilhelm Berliner, Albert Schreiber, Salomon Kauffmann, and Siegfried Goldschmidt. It remains to be explained who Louis Reichenberg was - a man never mentioned in any of the address lists or directories. Possibly, Louis Reichenbach, a merchant trading in wool and member of the Jewish community, is meant under this name. ${ }^{129}$ Thus, the Board would have been formed of eight Jewish and three Christian merchants.

The cast was diverse, composed of the most influential exponents of Christian and Jewish bourgeoisie. The most important among the Jews was, doubtlessly, Caro (1819-75), the owner of an immense fortune related to the iron-and-steel industry in Upper Silesia, and Friedenthal (1812-86), ${ }^{130}$ then-Deputy President of the Chamber of Commerce and head of the Jewish religious community. After Franck was not elected to chair the Chamber, Friedenthal took office and held it until his death. The other Jewish members of the Board (save for Berliner) sat, in parallel, on the Board of the Jewish community.

of the Board of the Royal Bank (renamed in 1871 as the Reichsbank), Chief Agent with the Aachen-Münchener Feuerversicherungsgesellschaft and Allgemeine Hagel Versicherungsgesellschaft in Weimar, member and Chairman of the Gesellschaft für vaterländische Cultur. See J.A. Franck's obituary in Breslauer Zeitung, lix, 477 (1878); also, Breslau address registers.

128 Statut des Breslauer Börsen Actien Vereins (Breslau, 1864), 6; Freymark, Die Handelskammer, 38.

${ }^{129} \dot{Z} \mathrm{IH}$, ref. no. $105 / 355,113$.

${ }^{130}$ A wholesale trader, Friedenthal was a member of the Board of the Upper Silesian Railway, founding member of the Silesian Society for Fire and Life Insurances, and a city councillor; see Freymark, Die Handelskammer, 48-9. 
The design for the Exchange building was selected by way of an architectural competition in 1864. The First Prize for a neo-Renaissance-style design was awarded to Dresden architects Ernst Giese and Bernhard Schreiber; however, it was a Neo-Gothic conception by Carl Johann Bogislaw Lüdecke that was selected for implementation. Lüdecke (1826-94) was one of the most talented Silesian architects of his time. The edifice was erected in $1865-7$ (Fig. 3). ${ }^{131}$ At the opening ceremony held on 19 June 1867, President of the Chamber of Commerce Franck argued as follows: "The more important and the more prominent the position of commerce and industry within the entire system of the state; the more resilient the development of both within our Province and our City; the greater the yearly increment in the number of merchants in here - the more legitimate and appropriate has the striving of our local merchantry become for forming a worthy residence of their own, one that would only be designed for minding their interests, and for their legal representatives to hold sessions, and therefore, to free themselves from the need to use premises unworthy of the dignity of the Breslau Chamber of Commerce and not inspiring the due respect". 132

The rivalry between representatives of the old merchantry associated in the Christian merchant corporation and the non-associated merchants, mainly Jewish, became the axis of the conflict in which Breslau's economic elites got involved in the first half of the nineteenth century. The conflict was characteristic of the period when the peculiar merchant ancien régime, stemming from the tradition of patricians who willed to keep the position they had enjoyed since the Middle Ages, clashed with the newly-emerging bourgeoisie and the influence groups associated with this class. The intent to depose the "post-medieval world' - the circle of those who, despite the revolutions occurring,

${ }^{131}$ For more on the competition and the Exchange building, see Agnieszka Zabłocka-Kos, 'Dawna "Nowa Giełda", obecnie siedziba klubu sportowego "Gwardia", ul. Krupnicza 15', in Jan Harasimowicz (ed.), Atlas architektury Wroctawia, i: Budowle sakralne. Świeckie budowle publiczne (Wrocław, 1997), 227-8; also eadem in Quart, lv (2020), no. 1 (in print); Janusz Dobesz, 'Gmach Nowej Giełdy we Wrocławiu. Projekty konkursowe', in Sztuka XIX wieku w Polsce. Naród - miasto. Materialy Sesji Stowarzyszenia Historyków Sztuki Poznań, grudzień 1977 (Warszawa, 1979), 209-31; Bożena Grzegorczyk, Pałace-instytucje. dziewiętnastowiecznego Wrocławia - znak patronatu obywatelskiego (Toruń, 2014), 240-53.

132 Freymark, Die Handelskammer, 38. 


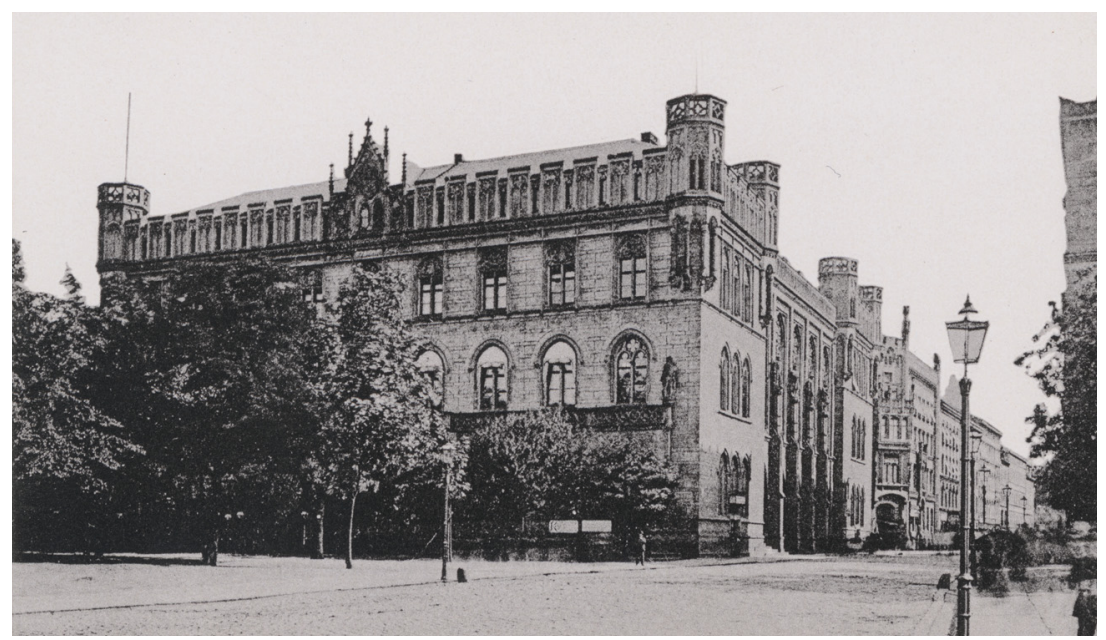

Fig. 3. View of the New Exchange, 1892, Kunstdruck-Anstalt Römmler \& Jonas, Königlich Sächsischer Hof-Photograph, Dresden. Mariusz Kotkowski’s private collection

would never acknowledge the change that overwhelmed the capitalist realities - coincided with Silesian traders' endeavours to regain Eastern markets. The Jewish economic elites were perceived as competitors or rivals; in parallel, they were indispensable for the reestablishment of commercial and business contacts with the East of Europe. Let us stress, though, that as years passed, the Christian-Jewish conflict gradually calmed down. In some economic initiatives - particularly those that called for a significant capital to be involved, as in railway and specific other industries - both parties collaborated peacefully and in mutual agreement. Family connections and marriages of grand families, founded upon religious conversions, favoured the trend. In the early 1860s, when the decision to build an exchange edifice was finally made, compromise and reconciliation were sought, rather than continued or exacerbating dispute. The new Exchange in Breslau brought an almost symbolic end to the conflicting interests, clashes, contestations, and exclusions that had been lasting there for two centuries. The Exchange was a collective project involving both Christian and Jewish trade and commerce circles united for the common goal - to rebuild the commercial power of Silesia's capital city and reinstate its leading role in trading between the West and the East. 
Once the conflicting parties finally arrived at a compromise and the most magnificent exchange edifice was built west of Berlin - in the 1860s decade - it seemed that these ideas might come true. However, the unification of Germany in 1871 thoroughly altered the position of Breslau. While doubtlessly remaining a vital metropolis of the German East, it had to give way to Leipzig as the critical intermediary in Central and Eastern European commerce and trade. The Breslau Exchange was de-ranked, becoming an institution of local importance. The building's outstanding architecture only attested its once-expected role in the European trade structure.

trans. Tristan Korecki

\section{SELECTED BIBLIOGRAPHY}

Baumgart Peter (ed.), unter Mitwirkung von Ulrich Schmilewski, Kontinuität und Wandel. Schlesien zwischen Österreich und Preußen (Sigmaringen, 1990).

Brämer Andreas, Herzig Arno, and Ruchniewicz Krzysztof (eds.), Jüdisches Leben zwischen Ost und West. Neue Beiträge zur jüdischen Geschichte in Schlesien, Reihe: Hamburger Beiträge zur Geschichte der deutschen Juden, xliv (Göttingen, 2014).

Brilling Bernhard, Geschichte der Juden in Breslau (1702-1725), in Jahrbuch der Schlesischen Friedrich Wilhelms Universität zu Breslau, xvi (1971), 88-126.

Brilling Bernhard, Geschichte der Juden in Breslau von 1454 bis 1702 (Stuttgart, 1960). Freymark Hermann, Die Handelskammer Breslau: 1849-1924. Festschrift der Industrieund Handelskammer Breslau (Breslau, 1924).

Herzig Arno, 900 Jahre jüdisches Leben in Schlesien (Görlitz, 2018).

Hettling Manfred, Reinke Andreas, and Conrads Norbert (eds.), In Breslau zu Hause? Juden in einer mitteleuropäischen Metropole der Neuzeit (Hamburg, 2003).

Van Rahden Till, Juden und andere Breslauer. Die Beziehungen zwischen Juden, Protestanten und Katholiken in einer deutschen Großstadt von 1860 bis 1925 (Göttingen, 2000).

Ziątkowski Leszek, Dzieje Żydów we Wrocławiu (Wrocław, 2000); German version: Die Geschichte der Juden in Breslau (Wrocław, 2000).

Ziątkowski Leszek, Ludność żydowska we Wrocławiu w latach 1812-1914 (Wrocław, 1998).

Ziątkowski Leszek, Między niemożliwym a koniecznym. Reformy państwa pruskiego w końcu XVIII $i$ na początku XIX wieku a proces równouprawnienia Żydów ze szczególnym uwzględnieniem sytuacji na Śląsku (Wrocław, 2007).

Agnieszka Zabłocka-Kos - architect and art historian, urban history of 19th- and 20th-century Central Europe; professor at the Institute of Art History, University of Wrocław; email: agnieszka.zablocka-kos@uwr.edu.pl 